УДК 616.89-008.441.13:577.175.823:159.9.072.5(=1-81)

Для цитирования: Попова Н.П., Егорова В.Е., Дуткин М.П., Полтавская Е.Г., Пожидаев И.В., Хоютанова Н.В., Османова Д.3. Полиморфизмы генов серотонинового рецептора HTR2A, триптофанпирролазы TDO2, уровень серотонина и психологические особенности при алкоголизме у коренных жителей Республики Саха (Якутия). Сибирский вестник психиатрии и наркологии. 2017; 4 (97): 15-21. https://doi.org/10.26617/1810-3111-2017-4(97)-15-21

\title{
Полиморфизмы генов серотонинового рецептора HTR2A, триптофанпирролазы TDO2, уровень серотонина и психологические особенности при алкоголизме у коренных жителей Республики Саха (Якутия)
}

\author{
Попова Н.П. ${ }^{1}$, Егорова В.Е. ${ }^{1}$, Дуткин М.П. ${ }^{1}$, Полтавская Е.Г. ${ }^{2}$, \\ Пожидаев И.В. ${ }^{2,3}$, Хоютанова Н.В. ${ }^{4}$, Османова Д.3.,3 \\ ${ }^{1}$ Северо-Восточный федеральный университет им. М.К. Амосова \\ 677000, Саха (Якутия), Якутск, ул. Белинского, д. 58 \\ ${ }^{2}$ Научно-исследовательский институт психического здоровья \\ Томский наџиональный исследовательский медицинский центр Российской академии наук \\ Россия, 634014, Томск, ул. Алеутская, 4 \\ ${ }^{3}$ Национальный исследовательский Томский государственный университет \\ Россия, 634050, Томск, пр. Ленина, 36 \\ ${ }^{4}$ Якутский республиканский наркологический диспансер \\ Россия, 677007, Саха (Якутия), Якутск, Автодорожная, 38
}

\section{PEЗЮME}

Проведено исследование содержания серотонина в периферической крови, генотипирование полиморфных вариантов генов серотонинового рецептора HTR2A (rs 6311) и триптофан-2,3-диоксигеназы (триптофанпирролазы) TDO2 (rs 2271537) и психологическое тестирование у коренных жителей арктического и субарктического поясов Республики Саха (Якутия), страдающих алкоголизмом и здоровых лиц. Результаты. Установлено, что у обследованных лиц из арктического пояса Республики Саха (Якутия) концентрация серотонина находится в физиологических пределах, однако средний уровень исследуемого амина ниже у жителей субарктического пояса в зимний период. Распределение частот генотипов и аллелей полиморфного варианта rs 2271537 гена TDO2 в популяциях якутов и эвенов достоверно не различается. Выявлена статистически значимая взаимосвязь генотипа Т/Т полиморфного варианта rs 6311 гена серотонинового рецептора HTR2A с низким уровнем серотонина, который в среднем достигал 43,8 62,0 нг/мл. Психологическое тестирование выявило враждебность у 57,6\% обследованных жителей субарктической зоны с генотипом А/C гена TDO2 (p=0,003). У женщин субарктического пояса с генотипом C/C rs 6311 гена HTR2A при сниженном уровне серотонина агрессивность в большинстве случаев отсутствовала или диагностировалась в пределах нормы $(\mathrm{p}=0,03)$.

Ключевые слова: алкоголизм, якуты, эвены, Республика Саха (Якутия), серотонин, ген триптофан-диоксигеназы TDO2, ген серотонинового рецептора HTR2A, психологические особенности.

\section{ВВЕДЕНИЕ}

Исследование алкоголизма представляется чрезвычайно актуальной проблемой и определяется её большим медицинским, социальным и экономическим бременем, связанным с высоким распространением и ежегодным увеличением заболеваемости, недостаточно четкими разработанными подходами к профилактике и лечению аддиктивных расстройств и этнокультуральными особенностями в различных популяциях $[1,2,3]$. В патогенезе алкогольной зависимости задействованы различные нейротрансмиттерные и гормональные системы, большое значение уделяется, прежде всего, нарушениям в дофаминовой и серотониновой нейротрансмиссии $[4,5,6]$. Серотонинергическая система мозга имеет непосредственное отношение к формированию аддиктивных расстройств, депрессивных состояний, а также агрессивного и импульсивного поведения, связанного с приемом психоактивных средств [7, 8, 6, 9].
Полифункциональность серотонина обусловлена наличием большого числа типов и подтипов его рецепторов с их разнообразной локализацией [10]. Концентрация серотонина и функционирование серотониновых рецепторов могут зависеть от полиморфных вариантов генов серотониновых рецепторов, транспортеров, ферментов, связанных с синтезом и метаболизмом серотонина. Так, триптофан2,3-диоксигеназа, ключевой фермент метаболизма триптофана, предшественника серотонина, расщепляет триптофан, уводя его метаболизм на киноурениновый путь, снижая его доступность для синтеза серотонина. В связи с этим при оценке предрасположенности к алкоголизму особое внимание уделяется анализу генетического полиморфизма серотониновых рецепторов подклассов 2А (5-НT2А), 2C (5-НТ2С) и триптофан-2,3-диоксигеназы.

Выявлены ассоциации полиморфизмов rs 6313 (102T/C в экзоне 1) и rs 6311 (-1438A/G) серотонинового рецептора 2А гена (HTR2A или 5-НT2A) с алкоголизмом и наркоманиями [11]. 
Показано, что психологические особенности зачастую коррелируют с генетическими полиморфизмами $[12,13]$. В ряде работ изучен вклад серотонинергической системы, в частности полиморфных локусов гена рецептора серотонина типа 2A 5HTR2A и 5-HTR2C, в развитие расстройств депрессивного спектра $[14,15,16]$. Таким образом, особый интерес представляет изучение функционирования серотонинергической системы, эмоциональных нарушений при длительном воздействии стрессирующих факторов в виде суровых климатических условий, полярного напряжения, недостаточности ультрафиолета при аддиктивных состояниях.

Цель исследования - анализ взаимосвязи психологических особенностей, уровня серотонина и полиморфизмов генов серотонинового рецептора HTR2A и триптофан-пирролазы у коренных жителей Республики Саха, страдающих алкоголизмом.

\section{МАТЕРИАЛЫ И МЕТОДЫ}

Исследование проводилось в соответствии с этическими принципами проведения исследований человека согласно протоколу, утвержденному локальным этическим комитетом НИИ психического здоровья. Обследовано 126 человек из ЭвеноБытантайского национального улуса (района) (субарктического пояса - САП), 135 человек из Нижнеколымского района (арктического пояса - АП) Республики Саха (Якутия) якутской, эвенской национальностей и других малочисленных народов Севера (чукчи, юкагиры) в возрасте от 21 до 68 лет, из них 130 больных алкоголизмом и 131 здоровых лиц. Основным инструментом исследования является Карта стандартизированного описания обследуемого по теме НИР «Патобиологические основы клинической гетерогенности психических и поведенческих расстройств вследствие употребления психоактивных веществ», разработанная в НИИ психического здоровья (авторы-составители: д.м.н., проф. Н.А. Бохан, д.м.н., проф. А.И. Мандель и др.).

Уровень тревожности и агрессии определяли методом психологического обследования с помощью опросников личностной и ситуативной тревожности Д. Спилбергера, Басса-Дарки. Для лабораторных исследований использована венозная кровь, взятая утром натощак, с 8:00 до 9:00, в вакутайнеры с ЭДТА (для дальнейшего выделения ДНК) и с активаторами свертывания (для получения сыворотки).

Генотипирование по полиморфному варианту rs 2271537 гена триптофан-пирролазы TDO2 и полиморфному варианту rs 6311 гена серотонинового рецептора HTR2A проводили методом полимеразноцепной реакции (ПЦР) в реальном времени с помощью амплификатора StepOnePlus (Applied Biosystems, США) и набора реагентов TaqMan®SNP Genotyping Assay фирмы (Applied Biosystems, США).

Определение концентрации серотонина в сыворотке крови проводили иммуноферментным методом с помощью наборов фирмы LDN (Labor Diagnostika Nord, Германия).

Статистическую обработку результатов производили с помощью программы SPSS 19. Все полученные частоты генотипов по исследуемым полиморфным локусам были проверены на соответствие равновесию Харди-Вайнберга с помощью критерия $\chi^{2}$. Сравнение частот генотипов в исследуемых группах проводили по критерию $\chi^{2}$. Различия считались достоверными при уровне значимости р <0,05.

\section{РЕЗУЛЬТАТЫ И ОБСУЖДЕНИЕ}

Перед представлением полученных результатов приводим краткое описание климатогеографических особенностей северных районов Республики Саха (Якутия), на территории которых проводились исследования. Необходимо отметить, что забор биологического материала производился в субарктическом поясе (Эвено-Бытантайский национальный район) в зимнее время, в арктическом поясе (Нижнеколымский район) - в весеннее время.

Расположение Эвено-Бытантайского национального улуса на крайнем северо-востоке Евразийского континента предопределило суровость его природных и климатических условий. На карте район обозначен под номером 34 (рис.1).



Р и с у н о к 1 - Карта административного деления Республики Саха (Якутия)

П р и м е ч а н и е. 20 - Нижнеколымский район, 34 - Эвено-Бытантайский национальный улус (район) 
Средние температуры в январе достигают $-50^{\circ} \mathrm{C}$, а в июле $+12,8^{\circ} \mathrm{C}$. Большая часть территории района относится к арктическому и субарктическому континентальному климатическим поясам. На всей территории распространена многолетняя мерзлота. Продолжительность зимнего периода свыше 8 месяцев. Климат резко-континентальный с годовой амплитудой колебания температуры более $100^{\circ} \mathrm{C}$. Длительность безморозного периода в среднем равняется 30 дням. Район является одним из самых труднодоступных улусов Якутии. Эвены составляют $32,25 \%$ жителей района.

Нижнеколымский район расположен на крайнем северо-востоке Якутии за Северным полярным кругом, на Колымской низменности. Средняя температура в январе от $-32{ }^{\circ} \mathrm{C}$ на севере до $-38{ }^{\circ} \mathrm{C}$ на юге, в июле колеблется от $+4{ }^{\circ} \mathrm{C}$ на севере до $+12{ }^{\circ} \mathrm{C}$ на юге. Осадков выпадает 150-200 мм в год, на карте район обозначен под номером 20 (рис. 1).

Согласно литературным данным, полярные ночи, короткий световой день являются причиной дефицита серотонина у коренных жителей арктических территорий. При недостаточности серотонина северяне испытывают проявления «полярного напряжения» с развитием депрессивной симптоматики. При анализе результатов нашего исследования у $43 \%$ жителей Эвено-Бытантайского района обнаружены низкие значения уровня серотонина при среднем значении 75,44 $\pm 89,5$ нг/мл. При этом выявлено статистически значимое снижение серотонина на $19 \%$ в контрольной группе $(\mathrm{p}=0,006)$. Сниженный уровень серотонина чаще наблюдался среди женщин $50,9 \%(\mathrm{p}=0,025)$ (рис. 2).

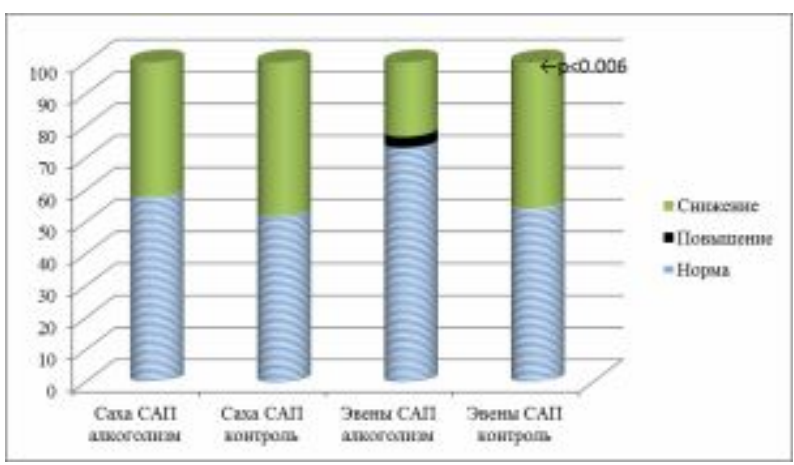

Р и с ун о к 2 - Уровень серотонина у жителей Эвено-Бытантайского района Республики Саха (Якутия)

Среднее значение уровня серотонина у жителей Нижнеколымского района в 4 раза превышало достигнутые показатели серотонина у обследованных из Эвено-Бытантайского района, составляя $321,33 \pm 178,7$ нг/мл, выявленные различия оказались статистически достоверно значимыми $(\mathrm{p}<0,001)$ (рис. 3).

Таким образом, у лиц, проживающих в условиях дискомфортного климата в зимнее время, регистрируется низкое содержание серотонина, его дефицит выявлен у $43 \%$ обследуемых.



Р и с ун о к 3 - Содержание серотонина в сыворотке периферической крови у жителей Нижнеколымского района Республики Саха (Якутия)

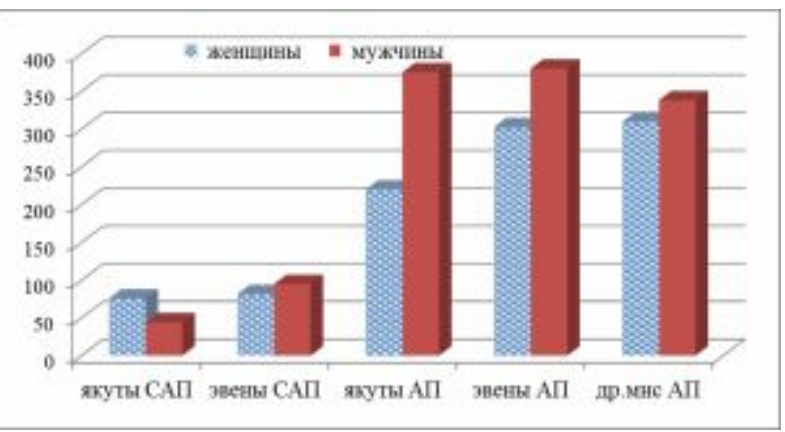

Р и с у н о к 4 - Средние значения серотонина (нг/мл) в объединенной выборке жителей арктического и субарктического поясов РС (Я) в зависимости от пола

При распределении по полу в объединенных выборках женщин и мужчин - жителей субарктического пояса в зимний период установлены низкие значения серотонина (рис. 4).

При дальнейшем анализе у женщин-эвенок САП контрольной группы в $52 \%$ случаев статистически значимо чаще встречается снижение уровня серотонина $(\mathrm{p}<0,001)$.

При анализе уровня серотонина в зависимости от этнической принадлежности выявлены следующие результаты. Снижение серотонина отмечено у $42 \%$ якутов и $23,3 \%$ эвенов САП (от 35,9 до 17,5 нг/мл и от 40,5 до 16,4 нг/мЛ соответственно; $\mathrm{p}=0,07$ и $\mathrm{p}=0,21)$. В выборке алкогольно-зависимых женщин среднее значение серотонина достигало у якуток 38,4 $\pm 18,36$ нг/мл $(p=0,075)$, у эвенок $77,65 \pm 15,93$ нг/мл $(\mathrm{p}<0,001)$.

В контрольной группе сниженный уровень серотонина установлен в зимнее время в $48 \%$ случаев у мужчин-якутов и у $45,7 \%$ мужчин-эвенов САП, средние значения серотонина в этих группах дости-

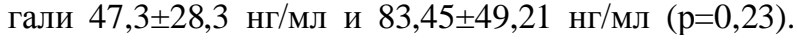
В группе здоровых женщин уровень серотонина снижен: в среднем у якуток - 80,1 22,3 нг/мл $(\mathrm{p}=0,003)$, у эвенок $-62,88 \pm 10,3$ нг/мл $(\mathrm{p}<0,001)$.

Статистически значимые результаты получены при анализе взаимосвязи алкоголизма с психологическими особенностями. У жителей субарктического пояса при алкоголизме выявлена высокая ситуативная тревожность ( $\mathrm{p}=0,025)$ (рис. 5). 




Р и с ун о к $5-$ Уровень ситуативной тревожности у жителей субарктического пояса РС (Я)

Распределение частот генотипов и аллелей исследуемого полиморфизма rs 2271537 гена TDO2 в объединенной группе якутов и эвенов субарктического пояса соответствовало равновесию ХардиВайнберга. В исследованной выборке генотип А/C в 53,6\% случаев встречается в контрольной группе, в $43,3 \%$ случаев - у больных алкоголизмом. Наименьшая частота генотипа A/A зарегистрирована в контрольной группе $(12,5 \%)$. Генотип $\mathrm{C} / \mathrm{C}$ наблюдается с одинаковой частотой в обеих группах (табл. 1). При этом у обследованных с генотипом A/C гена TDO2 в 57,6\% случаев обнаружена выраженная враждебность $(\mathrm{p}=0,003)$. Гомозиготы $\mathrm{C} / \mathrm{C}$ обеих групп (больные и контроль) имели низкие

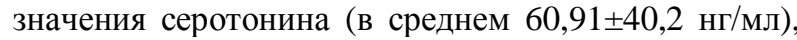
A/C (89,33 нг/мл), А/А (102,30 нг/мл). Гомозиготы C/C имели низкие значения серотонина (в среднем $60,91 \pm 40,2$ нг/мл), А/С (89,33 нг/мл), А/А $(102,30$ нг/Мл).

Т а б л и ц а 1

Распределение частот генотипов и аллелей гена TDO2 у больных с алкогольной зависимостью и в контрольных группах

\begin{tabular}{|c|c|c|c|c|c|c|c|}
\hline \multirow{3}{*}{\begin{tabular}{|c|} 
Группа об- \\
следованных
\end{tabular}} & \multirow{3}{*}{$\mathrm{n}$} & \multicolumn{5}{|c|}{ Частота } & \multirow{3}{*}{$\begin{array}{c}\chi^{2}(\mathrm{p}) \text { частот } \\
\text { генотипов/ } \\
\text { аллелей }\end{array}$} \\
\hline & & \multicolumn{3}{|c|}{ генотипов } & \multicolumn{2}{|c|}{ аллелей } & \\
\hline & & $\mathrm{A} / \mathrm{A}$ & $\mathrm{A} / \mathrm{C}$ & $\mathrm{C} / \mathrm{C}$ & A & $\mathrm{C}$ & \\
\hline Больные & 60 & 0,233 & 0,433 & 0,333 & 0,450 & 0,550 & $2,51(0,29) /$ \\
\hline Контроль & 56 & 0,125 & 0,536 & 0,339 & 0,393 & 0,607 & $0,78(0,38)$ \\
\hline
\end{tabular}

Распределение частот генотипов и аллелей исследуемого полиморфизма rs 6311 гена HTR2A в объединенной группе якутов и эвенов субарктического пояса соответствовало равновесию ХардиВайнберга.

Т а б ли ц а 2

Распределение частот генотипов и аллелей гена HTR2A (rs 6311) у больных с алкогольной зависимостью и в контрольных группах

\begin{tabular}{|c|c|c|c|c|c|c|c|}
\hline \multirow{3}{*}{\begin{tabular}{|c|} 
Группа об- \\
следованных
\end{tabular}} & \multirow{3}{*}{ n } & \multicolumn{5}{|c|}{ Частота } & \multirow{3}{*}{$\begin{array}{c}\chi^{2}(\mathrm{p}) \text { частот } \\
\text { генотипов/ } \\
\text { аллелей }\end{array}$} \\
\hline & & \multicolumn{3}{|c|}{ генотипов } & \multicolumn{2}{|l|}{ алл } & \\
\hline & & & & & & $\overline{\mathrm{C}}$ & \\
\hline & 57 & & & & & 93 & \\
\hline $\mathrm{OH}^{2}$ & 49 & 0,653 & 0,327 & 0,020 & 0,816 & 0,184 & 0,03 \\
\hline
\end{tabular}

В общей выборке среди больных алкоголизмом разных национальностей достоверно значимых различий также не обнаружено. В обеих исследуемых группах обращает на себя внимание двукратное снижение частоты гомозигот T/Т в группе контроля и увеличение частоты генотипа T/T среди больных $\left(\mathrm{p}=0,53, \chi^{2}=0,89\right)$. Изменения частот генотипов $\mathrm{C} / \mathrm{C}$ и $\mathrm{C} / \mathrm{T}$ по сравнению с контрольной группой различий не обнаружили. В группе женщин гомозиготы T/T прямо коррелировали с низким уровнем серото-

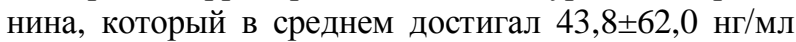

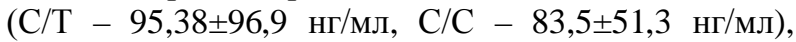
у мужчин с генотипом T/T среднее значение серото-

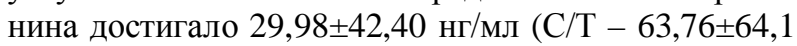
нг/мл, С/С - 77,8 $\pm 140,0$ нг/мл).

\section{ЗАКЛЮЧЕНИЕ}

Таким образом, у обследованных лиц из арктического пояса Республики Саха (Якутия) концентрация серотонина находится в физиологических пределах, однако средний уровень серотонина ниже у жителей субарктического пояса в зимний период. Гипотетически возможны несколько причин более низкого содержания серотонина в крови жителей субарктического пояса. Во-первых, это может быть связано с сезонностью, в наших исследованиях сезонные различия оказались достоверными ( $<<0,001)$. Во-вторых, злоупотребление алкоголем не явилось усугубляющим фактором, в обеих группах эвенов и якутов субарктического пояса был выявлен изначально сниженный уровень серотонина в зимний период независимо от злоупотребления алкоголем, что не соответствует литературным данным $[16,17$, $18,19]$. При этом в контрольной группе наблюдалось статистически значимое снижение серотонина на $19 \%(p=0,006)$. Причем сниженный уровень серотонина чаще наблюдался среди женщин $(50,9 \%)$ $(\mathrm{p}=0,025)$.

Сниженный уровень серотонина среди женщин группы контроля указывает на необходимость мониторинга и своевременного выявления депрессивных состояний среди женского населения и лиц, мигрировавших в арктические районы республики, с проведением профилактических мероприятий при помощи светотерапии. При этом рекомендуется создание кабинетов светотерапии при образовательных учреждениях и учреждениях здравоохранения в арктических районах республики.

Статистически значимые результаты получены при анализе взаимосвязи алкоголизма и психологических особенностей. У жителей субарктического пояса при алкоголизме выявлена высокая ситуативная тревожность $(\mathrm{p}=0,025)$. Психологические исследования выявили враждебность у $57,6 \%$ обследованных с генотипом A/C гена TDO2 ( $\mathrm{p}=0,003)$. $\mathrm{У}$ женщин субарктического пояса с генотипом $\mathrm{C} / \mathrm{C}$ rs 6311 гена HTR2A при сниженном уровне серотонина в большинстве случаев агрессивность отсутствовала или диагностировалась в пределах нормы $(\mathrm{p}=0,03)$. При установленных изменениях уровня серотонина и уровня враждебности среди обследованных лиц высокая агрессивность не диагностирована, что противоречит литературным данным [20]. Данный факт указывает на необходимость разработки адаптированных психологических методик выяв- 
ления агрессивных состояний у коренного населения республики.

\section{КОНФЛИКТ ИНТЕРЕСОВ}

Авторы заявляют об отсутствии конфликта интересов в связи с публикацией данной статьи.

\section{ИСТОЧНИК ФИНАНСИРОВАНИЯ}

Статья подготовлена по результатам проекта «Многофакторное исследование состояния здоровья коренного и пришлого населения РС (Я) с целью оптимизации региональных программ по улучшению качества жизни жителей республики с учетом территориальных, этнических особенностей в условиях современного социально-экономического развития», Программы комплексных научных исследований в Республике Саха (Якутия), направленных на развитие её производительных сил и социальной сферы на 2016-2020 гг.

\section{СООТВЕТСТВИЕ ПРИНЦИПАМ ЭТИКИ}

Исследование проведено с соблюдением норм современной биомедицинской этики и этических стандартов, разработанным в соответствии с Хельсинской декларацией ВМА (протокол заседания этического комитета НИИ психического здоровья № 53 от 01.10.2012 г.).

\section{ЛИТЕРАТУРА}

1. Мандель А.И., Артемьев И.А., Ветлугина Т.П., Иванова С.А. Невидимова Т.И., Прокопьева В.Д., Аболонин А.Ф., Шушпанова Т.В. Биологические предикторы, клинико-патогенетические механизмы формирования и профилактика аддиктивных состояний в различных социальных группах. Сибирский вестник психиатрии и наркологии. 2013; 4 (79): 40-48.

2. Хоютанова Н.В., Матвеева Н.П., Бохан Н.А., Иванова С.А., Кривошапкина 3.Н., Иготти Е.А. Клинико-динамические особенности формирования и течения алкоголизма у женщин в зависимости от климатогеографических условий проживания на территории РС (Я). Якутский медицинский журнал. 2015; 1 (49): 14-18.

3. Бохан Н.А., Мандель А.И., Иванова С.А., Прокопьева В.Д., Артемьев И.А., Невидимова Т.И., Батухтина Е.И., Воеводин И.В., Аболонин А.Ф., Шушпанова Т.В. Старые и новые проблемы наркологии в контексте междисциплинарных исследований. Вопросы наркологии. 2017; 1: 26-62.

4. Де Витт Ф. Влияние алкоголя на нейромедиаторные системы мозга. Вопросы наркологии. 2002; 1: 55-56.

5. Анохина И.П. Биологические механизмы предрасположенности к зависимости от психоактивных веществ. Психиатрия и психофармакотерапия. 2007; 1: 10-14.

6. Бохан Н.А., Иванова С.А., Левчук Л.А. Серотониновая система в модуляции депрессивного и аддиктивного поведения. Томск: Изд-во Том. ун-та, 2013:102.

7. Семке В.Я., Гусев С.И., Снигирева Г.Я. Пенитенциарная психология и психопатология: руководство в 2-х т. / Под ред. Т.Б. Дмитриевой, В.Я. Семке, А.С. Кононца. Москва; Томск; Кемерово, 2007; 1: 576.

8. Стояк В.А. Нейромедиаторные системы в регуляции агрессивного поведения. Сибирский вестник психиатрии и наркологии. 2010; 3 (60): 70-76.

9. Loonen A.J.M., Ivanova S.A. Role of 5-HT2C receptors in dyskinesia. International Journal of Pharmacy and Pharmaceutical Sciences. 2016; 8 (1): 5-10.

10. Ашмарин И.П., Ещенко Н.Д., Каразеева Е.П. Нейрохимия в таблицах и схемах. М.: Изд-во «Экзамен», 2007: 40-47.

11. Jian Cao, Xiangtao Liu, Shizhong Han, Clarence K. Zhang et al. Association of the HTR2A Gene with Alcohol and Heroin Abuse. Hum Genet. 2014; 133 (3): 357-365. doi:10.1007/s00439-0131388-y.

12. Рядовая Л.А., Гуткевич Е.В., Стоянова И.Я., Иванова С.А Полиморфизм генов серотонинового обмена и мотивационно-потребностная сфера личности. Вестник ТГПУ. 2009; 3 (81): 49-53.

13. Гаврилова В.А. Клинико-патофизиологические особенности гормонального фона и полиморфизмы генов серотониновой системы у больных алкоголизмом с противоправным поведением : автореф. дис. ... к.м.н. Томск, 2012: 26.

14. Рядовая Л.А., Гуткевич Е.В., Лаврушина О.М., Иванова С.А., Семке В.А. Изучение полиморфных вариантов гена рецептора серотонина типа 2A 5-HTR2A при пограничных психических расстройствах. Сибирский вестник психиатрии и наркологии. 2007; 4 (47): 12-15.

15. Левчук Л.А., Лосенков И.С., Вялова Н.М., Шмиголь М.В., Лебедева Е.В., Симуткин Г.Г., Иванова С.А. Ассоциация полиморфизма гена рецептора серотонина 2C (HTR2C) с депрессивными расстройствами. Фундаментальные исследования. 2013; 1 (2): 299-303.

16. Буров Ю.В., Смольникова Н.М., Ходорова Н.А. Влияние алкоголизации на уровень серотонина в головном мозге и скорость элиминации этанола у потомства крыс. Фармакология и токсикология. 1983; XLVI (6): 51-53.

17. Жуков В.Н., Ходорова Н.А., Буров Ю.В. Содержание серотонина в разных отделах головного мозга, печени, кишечнике, крови у крыс, предрасположенных и непредрасположенных к потреблению алкоголя. Бюллетень экспериментальной биологии и медицины. 1982; 7: 35-37.

18. Максимова Н.М., Узбеков М.Г., Вертоградова О.П., Мисионжник Э.Ю. и др. Актуальные вопросы теоретической и клинической психоэндокринологии: сборник научных трудов. М., 2007: 118-127.

19. Маркозова Л. М., Усменцева Е.И. Взаимосвязь серотонина и клинико-психопатологических проявлений у лиц с различными вариантами аффективных расстройств при алкогольной зависимости. Психическое здоровье. 2009; 2: 34-38.

20. Anderson M., Deakin J.F.W. Relationship between 5-HT function and impulsivity and aggression in male offenders with personality disorders. The British Journal of Psychiatry. 2001; 178: $352-359$.

Поступила в редакцию 4.03.2017 Утверждена к печати 30.10 .2017

Попова Нюргуяна Петровна, к.м.н., н.с. УНЛ «Геномная медицина» Клиники Медицинского института.

Егорова Виктория Егоровна, зав. учебно-научной клинико-диагностической лабораторией клиники медицинского института.

Дуткин Максим Петрович, к.фил.н., доцент кафедры неврологии и психиатрии медицинского института.

Полтавская Евгения Григорьевна, н.с. отдела биологической психиатрии и наркологии

Пожидаев Иван Вячеславович, м.н.с. отдела биологической психиатрии и наркологии.

Хоютанова Надежда Васильевна, врач психиатр-нарколог.

Османова Диана Закировна, м.н.с. отдела биологической психиатрии и наркологии.

Попова Нюргуяна Петровна, nyusakha@ mail.ru 
УДК 616.89-008.441.13:577.175.823:159.9.072.5(=1-81)

For citation: Popova N.P., Yegorova V.E., Dutkin M.P., Poltavskaya E.G., Pozhidaev I.V., Khoyutanova N.V., Osmanova D.Z. Polymorphisms of the genes of the serotonin receptor HTR2A, of tryptophan pyrrolase TDO2, the level of serotonin and psychological traits in the natives with alcoholism of the Republic of Sakha (Yakutia). Siberian Herald of Psychiatry and Addiction Psychiatry. 2017; 4 (97): 15-21. https://doi.org/10.26617/1810-3111-2017-4(97)-15-21

\section{Polymorphisms of the genes of the serotonin receptor HTR2A, of tryptophan pyrrolase TDO2, the level of serotonin and psychological traits in the natives with alcoholism of the Republic of Sakha (Yakutia)}

\section{Popova N.P. ${ }^{1}$, Yegorova V.E. ${ }^{1}$, Dutkin M.P. ${ }^{1}$, Poltavskaya E.G. ${ }^{2}$, Pozhidaev I.V. ${ }^{2,3}$, Khoyutanova N.V.. ${ }^{4}$ Osmanova D.Z. ${ }^{2,3}$}

${ }^{1}$ M.K. Amosov North-East Federal University Belinsky Street 58, 677000, Yakutsk, Sakha (Yakutia), Russian Federation

${ }^{2}$ Mental Health Research Institute, Tomsk National Research Medical Center, Russian Academy of Sciences Aleutskaya Street 4, 634014, Tomsk, Russian Federation

${ }^{3}$ National Research Tomsk State University

Lenin Avenue 36, 634050, Tomsk, Russian Federation

${ }^{4}$ Yakut Republican Narcological Dispensary

Avtodorozhnaya Street 38, 677007, Yakutsk, Sakha (Yakutia), Russian Federation

\section{ABSTRACT}

The contents of serotonin in peripheral venous blood of the indigenous people of the Arctic and subarctic zones of the Republic of Sakha (Yakutia) aged 21-68 years are studied and compared with the analysis results of single nucleotide polymorphism rs 6311 HTR2A serotonin receptor gene and the tryptophan 2,3-dioxygenase (tryptophan pyrrolase) TDO2 association with the alcoholism and psychological traits. Results. It is found that the surveyed persons from the Arctic zone of the Republic of Sakha (Yakutia) have concentration of serotonin in the physiological range, but the average level of the test amine is lower in the inhabitants of the subarctic zone in winter. Polymorphism A>C (rs 2271537) in the gene for tryptophan 2,3-dioxygenase (tryptophan pyrrolase) TDO2 in patients with alcohol dependence of Yakut and Even nationalities from subarctic zone of the Republic of Sakha (Yakutia) by polymerase chain reaction of DNA synthesis is performed. It is found that the frequency distribution of genotypes and alleles of the gene in populations TDO2 of Yakuts and Evens is not significantly different. A significant correlation of the genotype T/T gene HTR2A with low levels of serotonin is revealed, which reaches an average of 43,8 $\pm 62,0 \mathrm{ng} / \mathrm{ml}$. Psychological studies reveal hostility in $57.6 \%$ of those examined with the genotype $\mathrm{A} / \mathrm{C}$ of the $\mathrm{TDO} 2$ gene $(\mathrm{p}=0.003)$. In women of the subarctic zone with genotype $\mathrm{C} / \mathrm{C}$ rs 6311 of the HTR2A gene with a decreased serotonin level, in most cases aggressiveness is absent or diagnosed within the normal range $(\mathrm{p}=0.03)$.

Keywords: alcoholism, Yakuts, Evens, the Republic of Sakha (Yakutia), serotonin, tryptophan dioxygenase gene TDO2, gene HTR2A serotonin receptor, psychological traits

\section{REFERENCES}

1. Mandel' A. I., Artem'ev I. A., Vetlugina T. P., Ivanova S. A. Nevidimova T. I., Prokop'eva V. D., Abolonin A. F., Shushpanova T.V. Biologicheskie prediktory, kliniko-patogeneticheskie mekhanizmy formirovaniya i profilaktika addiktivnyh sostoyanij $\mathrm{v}$ razlichnyh social'nyh gruppah [Biological predictors, clinicalpathogenetic mechanisms of formation and prevention of addictive states in various social groups]. Sibirskij vestnik psihiatrii narkologii - Siberian Herald of Psychiatry and Addiction Psychiatry. 2013; 4 (79): 40-48 (in Russian).

2. Khoyutanova N.V., Matveeva N.P., Bokhan N.A., Ivanova S.A., Krivoshapkina Z.N., Igotti E.A. Kliniko-dinamicheskie osobennosti formirovaniya $\mathrm{i}$ techeniya alkogolizma $\mathrm{u}$ zhenshchin $\mathrm{v}$ zavisimosti ot klimatogeograficheskih uslovij prozhivaniya na territorii RS(YA) [Clinical - dynamic characteristic of formation and course of alcoholism at women depending on climaticgeographic living conditions in the territory of the Republic of Sakha (Yakutia)]. Yakutskij medicinskij zhurnal - Yakut Medical Journal. 2015; 1 (49): 14-18 (in Russian).

3. Bokhan N.A., Mandel' A.I., Ivanova S.A., Prokop'eva V.D., Artem'ev I.A., Nevidimova T.I., Batukhtina E.I., Voevodin I.V., Abolonin A.F., Shushpanova T.V. Starye i novye problemy narkologii $\mathrm{v}$ kontekste mezhdisciplinarnyh issledovanij [Old and new issues of addiction medicine in the context of interdisciplinary research]. Voprosy narkologii - Journal of Addiction Problems. 2017; 1: 2662 (in Russian).
4. De Vitt F. Vlijanie alkogolja na nejromediatornye sistemy mozga [Influence of alcohol on brain neuromediator systems]. Voprosy narkologii - Journal of Addiction Problems. 2002; 1: 5556 (in Russian).

5. Anokhina I.P. Biologicheskie mekhanizmy predraspolozhennosti $\mathrm{k}$ zavisimosti ot psihoaktivnyh veshchestv [Biological mechanisms of predisposition to substance dependence]. Psihiatriya $i$ psihofarmakoterapiya - Psychiatry and Psychopharmacotherapy. 2007; 1: 10-14 (in Russian).

6. Bokhan N.A., Ivanova S.A., Levchuk L.A. Serotoninovaya sistema $\mathrm{v}$ modulyacii depressivnogo i addiktivnogo povedeniya [Serotonin system in modulation of depressive and addictive behavior]. Tomsk: Izd-vo Tom. un-ta, 2013: 102 (in Russian).

7. Semke V.Ya, Gusev S.I., Snigireva G.Ya. Penitenciarnaya psihologiya i psihopatologiya: rukovodstvo [Penitentiary psychology and psychopathology: Handbook]. 2 volumes. T.B. Dmitrieva, V.Ya. Semke, A.S. Kononets, eds. Moskow; Tomsk; Kemerovo, 2007; 1: 576 (in Russian).

8. Stoyak V.A. Nejromediatornye sistemy $\mathrm{v}$ regulyacii agressivnogo povedeniya [Neuromediator systems in regulation of aggressive behavior]. Sibirskij vestnik psihiatrii i narkologii - Siberian Herald of Psychiatry and Addiction Psychiatry. 2010; 3 (60): 70-76 (in Russian).

9. Loonen A.J.M., Ivanova S.A. Role of 5-HT2C receptors in dyskinesia. International Journal of Pharmacy and Pharmaceutical Sciences. 2016; 8 (1): 5-10. 
10. Ashmarin I.P., Eshchenko N.D., Karazeeva E.P. Nejrohimiya v tablicah i skhemah. M.: Izdatel'stvo Ehkzamen», 2007: 40-47.

11. Jian Cao, Xiangtao Liu, Shizhong Han, Clarence K. Zhang et al. Association of the HTR2A Gene with Alcohol and Heroin Abuse. Hum Genet. 2014133 (3): 357-365. doi:10.1007/s00439-0131388-y.

12. Ryadovaya L.A., Gutkevich E.V., Stoyanova I.Ya., Ivanova S.A Polimorfizm genov serotoninovogo obmena i motivacionnopotrebnostnaya sfera lichnosti [Gene polymorphism of serotonin metabolism in personality motivational-need realm]. Vestnik TGPU - Tomsk State Pedagogical University Bulletin. 2009; 3 (81): 49-53 (in Russian).

13. Gavrilova V.A. Kliniko-patofiziologicheskie osobennosti gormonal'nogo fona i polimorfizmy genov serotoninovoj sistemy u bol'nyh alkogolizmom s protivopravnym povedeniem [Clinicalpathophysiological features of endocrine profile and gene polymorphisms of serotonin system in alcoholic pateints with offensive behavior]. Avtoref. dis. ... kand. med. nauk - Abstract of PhD thesis. Tomsk, 2012: 26 (in Russian).

14. Ryadovaya L.A., Gutkevich E.V., Lavrushina O.M., Ivanova S.A., Semke V.A. Izuchenie polimorfnyh variantov gena receptora serotonina tipa 2A 5-HTR2A pri pogranichnyh psihicheskih rasstrojstvah [Study of polymorphic variants of the gene of the receptor serotonin of type 2A 5-HTR2A in borderline mental disorders]. Sibirskij vestnik psihiatrii $i$ narkologii - Siberian Herald of Psychiatry and Addiction Psychiatry. 2007; 4 (47): 12-15 (in Russian).

15. Levchuk L.A., Losenkov I.S., Vyalova N.M., Shmigol' M.V., Lebedeva E.V., Simutkin G.G., Ivanova S.A. Associaciya polimorfizma gena receptora serotonina 2S (HTR2C) s depressivnymi rasstrojstvami [Polymorphism of serotonin $2 \mathrm{C}$ receptor gene (HTR2C) in patients with depressive disorders]. Fundamental'nye issledovaniya - Fundamental Studies. 2013; 1 (2): 299-303 (in Russian).
16. Burov Yu.V., Smol'nikova N.M., Hodorova N.A. Vliyanie alkogolizacii na uroven' serotonina v golovnom mozge i skorost' ehliminacii ehtanola u potomstva krys [Influence of alcoholization on level of serotonin in brain and ethanol elimination speed in offspring of rats]. Farmakologiya i toksikologiya - Pharmacology and Toxicology. 1983; XLVI (6): 51-53 (in Russian).

17. Zhukov V.N., Hodorova N.A., Burov Yu.V. Soderzhanie serotonina v raznyh otdelah golovnogo mozga, pecheni, kishechnike, krovi u krys, predraspolozhennyh i nepredraspolozhennyh k potrebleniyu alkogolya [Content of serotonin in different brain regions, liver, intestine, blood in rats predisposed and not predisposed to alcohol use]. Byulleten' ehksperimental'noj biologii $i$ mediciny - Bulletin of Experimental Biology and Medicine. 1982; 7: 35-37 (in Russian).

18. Maksimova N.M., Uzbekov M.G., Vertogradova O.P., Misionzhnik E.Yu. i dr. Aktual'nye voprosy teoreticheskoj i klinicheskoj psihoehndokrinologii: sbornik nauchnyh trudov [Relevant issues of theoretical and clinical psychoendocrinology: collection of scientific works]. M., 2007: 118-127 (in Russian).

19. Markozova L.M., Usmenceva E.I. Vzaimosvyaz' serotonina i kliniko-psihopatologicheskih proyavlenij u lic s razlichnymi variantami affektivnyh rasstrojstv pri alkogol'noj zavisimosti [Serotonin and clinical manifestations' interdependences at patients with alcohol dependency with various variants of emotionally disorders]. Psihicheskoe zdorov'e - Mental Health. 2009; 2: 34-38 (in Russian).

20. Anderson M., Deakin J.F.W. Relationship between 5-HT function and impulsivity and aggression in male offenders with personality disorders. The British Journal of Psychiatry. 2001; 178: $352-359$.

Received March 4.2017 Accepted October 30.2017

Popova Nyurguyana P., PhD, researcher of ESL "Genomic Medicine" of Clinics of Medical Institute, M.K. Amosov North-East Federal University, Yakutsk, Sakha (Yakutia), Russian Federation.

Yegorova Victoria E., Head of Educational-Scientific Clinical-Diagnostic Laboratory of Clinics of Medical Institute, M.K. Amosov North-East Federal University, Yakutsk, Sakha (Yakutia), Russian Federation.

Dutkin Maxim P., Candidate of Philology, senior lecturer of Neurology and Psychiatry Department of Medical Institute, M.K. Amosov North-East Federal University, Yakutsk, Sakha (Yakutia), Russian Federation.

Poltavskaya Evgenia G. researcher of Biological Psychiatry and Narcology Department, Mental Health Research Institute, Tomsk National Research Medical Center, Russian Academy of Sciences, Tomsk, Russian Federation.

Pozhidaev Ivan V., junior researcher of Biological Psychiatry and Narcology Department, Mental Health Research Institute, Tomsk National Research Medical Center, Russian Academy of Sciences, Tomsk, Russian Federation; National Research Tomsk State University, Tomsk, Russian Federation.

Hoyutanova Nadezhda V., psychiatrist-addiction specialist, Yakut Republican Narcological Dispensary, Yakutsk, Sakha (Yakutia), Russian Federation.

Osmanova Diana Z., junior researcher of Biological Psychiatry and Narcology Department, Mental Health Research Institute, Tomsk National Research Medical Center, Russian Academy of Sciences, Tomsk, Russian Federation; National Research Tomsk State University, Tomsk, Russian Federation. 